\title{
EXPLORING DETERMINANTS OF CUSTOMERS' INTENTION TO ADOPT GREEN BANKING: QUALITATIVE INVESTIGATION
}

\author{
MOHAMED BOUTERAA*, RAJA RIZAL ISKANDAR RAJA HISHAM AND ZAIRANI \\ ZAINOL
}

College of Business (COB), Universiti Utara Malaysia (UUM), Sintok 06010 Kedah, Malaysia.

*Corresponding author: bouteraa.med@hotmail.com

Submitted final draft: 10 June $2020 \quad$ Accepted: 25 June $2020 \quad$ http://doi.org/10.46754/jssm.2021.04.014

\begin{abstract}
Banks and financial institutions need to invest in green banking now more than ever if they hope to survive and counteract or minimise the damage done to the environment as a side effect of previously unchecked growth, greed and corruption in the financial sector. Green Banking (GB) refers to financial products and services related to the use of information technology, to protect the environment and improve social welfare by delivering alternative, more efficient financial facilities with durable protection at reduced costs, compared to conventional banking services. Despite GB's wide range of benefits, this trend is new in developing countries and some of them, including the United Arab Emirates (UAE) are facing issues with the low adoption of GB, which is a cause for concern. The purpose of this paper is to explore the determinants of customers' intentions to adopt GB practices. In order to achieve this objective, the research paper was designed as a qualitative semi-structured interview that gathered data from ten bank professionals. The data was analysed using Thematic Content Analysis on NVivo 11 software. The output of the study proposed an innovative model by integrating eight new essential determinants to Unified Theory of Acceptance and Use of Technology (UTAUT) to capture customers' intention to adopt GB initiatives. The study has the potential to provide a better understanding for bankers to design the proper interventions regarding the adoption of GB initiatives that would drive more sustainability.
\end{abstract}

Keywords: Green Banking, Sustainable Development, Intention to Adopt.

Abbreviations: "GB= Green Banking, $S D G=$ Sustainable Development Growth, UAE= United Arab Emirates, UNEP-FI= Nations Environment Programme-Finance Initiative, UNPRI = United Nations Principles for Responsible Investment, MoCCAE = Ministry of Climate Change and Environment, MoEW =Ministry of Environment and Water."

\section{Introduction}

Over the past three decades, there has been considerably more attention paid towards environmental protection and Sustainable Development Growth (SDG) due to increasing global environment degradation and loss facing present and future generations (Shantha, 2019; Tara et al., 2019).

Indeed, environmentalism has been recognised as the major business issue of the 90's (Grove et al., 1996). This resulted in world leaders making a collective effort to initiate sustainable frameworks for their developmental activities through volunteer codes of conduct like the United Nations Environment Programme-
Finance Initiative (UNEP-FI), the Equator Principles for Project Finance and the United Nation Principles for Responsible Investment (UNPRI), in order to address environmental issues such as global warming, acid rain, air and water pollution, ozone layer depletion and climate change, that affect all living beings (World Bank, 2017).

This ongoing trend has given rise to the "Go Green" concept, which has become the buzzword of financial-world nowadays due to the alarming increase in the rate of climate change and global warming (Zhixia et al., 2018; Samina \& Hossain, 2019; Yin et al., 2019; Bouteraa et al., 2020). Following this, the concept of Green Banking (GB) has emerged 
as a means for banks and financial institutions to reduce their carbon footprint and attain environmental sustainability.

Environmental sustainability remains a major issue in many developing countries, which requires the use of appropriate strategies to reduce the impact of banking activities on the environment.

Sustainable development is central to the United Arab Emirates (UAE) present and future business development initiatives as it has the world's most significant ecological footprint (The World Wide Fund for Nature [WWFN], 2010; Government.ae, 2018; Worldatlas, 2019). The World Bank Group (2018) also reported the UAE as having record high pollution levels and violent $\mathrm{CO} 2$ carbon emission increases as a result of human and business activity. Therefore, the government of the UAE has been unwontedly serious in handling the problem and has taken significant environmentally-friendly steps, including amending legislations, developing regulations and guidance on green financing as well as making it compulsory for all financial institutions to follow a green financing strategy (Bouteraa, 2020).

The purpose of the new inclusion in the banking sector is targeted at promoting the UAE Green Agenda 2030 vision and ensuring proper SDGs (UAE Climate Change and Environment Ministry [UAE-MOCCAE], 2017).

Despite the considerable green initiatives and the wide range benefits offered by GB initiatives to consumers, banks, industries and the economy, it is a challenging task, and customers and private businesses in the UAE are still in the primary stages of adoption. However, the effective introduction of GB needs the participation of bank customers, since they are at the forefront of utilising these measures to carry out their banking transactions (Iqbal et al., 2018).

In order to gain insights into this issue, the UAE-MoEW, in cooperation with the UAE Central Bank and the UNEP-FI, conducted the first ever national survey to identify the adoption level of GB products and services in the UAE. Surprisingly, the findings showed that the majority of the green products and projects under review had either failed or were abandoned, while other projects received only shallow adoption rates or were rejected, as shown in Figure 1 (UAE Ministry of Environment and Water [UAE-MoEW], 2016).

The most striking finding was that 59\% of respondents did not have any intentions of adopting GB products and services in future (UAE-MoEW, 2016). These frightening statistics highlight the importance of delivering the right tools to bankers to help them resolve the issue as this phenomenon raises numerous issues with the adoption of sustainable business practices.

This paper is motivated to explore the determinants of low adoption of GB products and services among customers. Based on an exploratory investigation, the output of this study is expected to serve as a reference for scholars in order to recognise the drivers of customers intention to adopt GB practices, as well as provide guidance for policymakers, decision-makers, and bank practitioners as this study aims to enlighten them by providing a better understanding of the actual issues and challenges facing customers that want to adopt GB practices.

This study will also allow policymakers to design the proper intervention and increase GB adoption rates that would drive the principles of SDG and environmental sustainability.

\section{Literature Review}

In October 2016, the UAE officially introduced green initiatives for the financial sector (MOCCAE, 2017). Following which, it has become mandatory for all financial institutions and banks in the country to adopt a GB framework in a formal manner (UAEMOCCAE, 2017).

A new trend was observed in the literature upon the introduction of the GB policy, in which researchers aimed to describe the challenges 


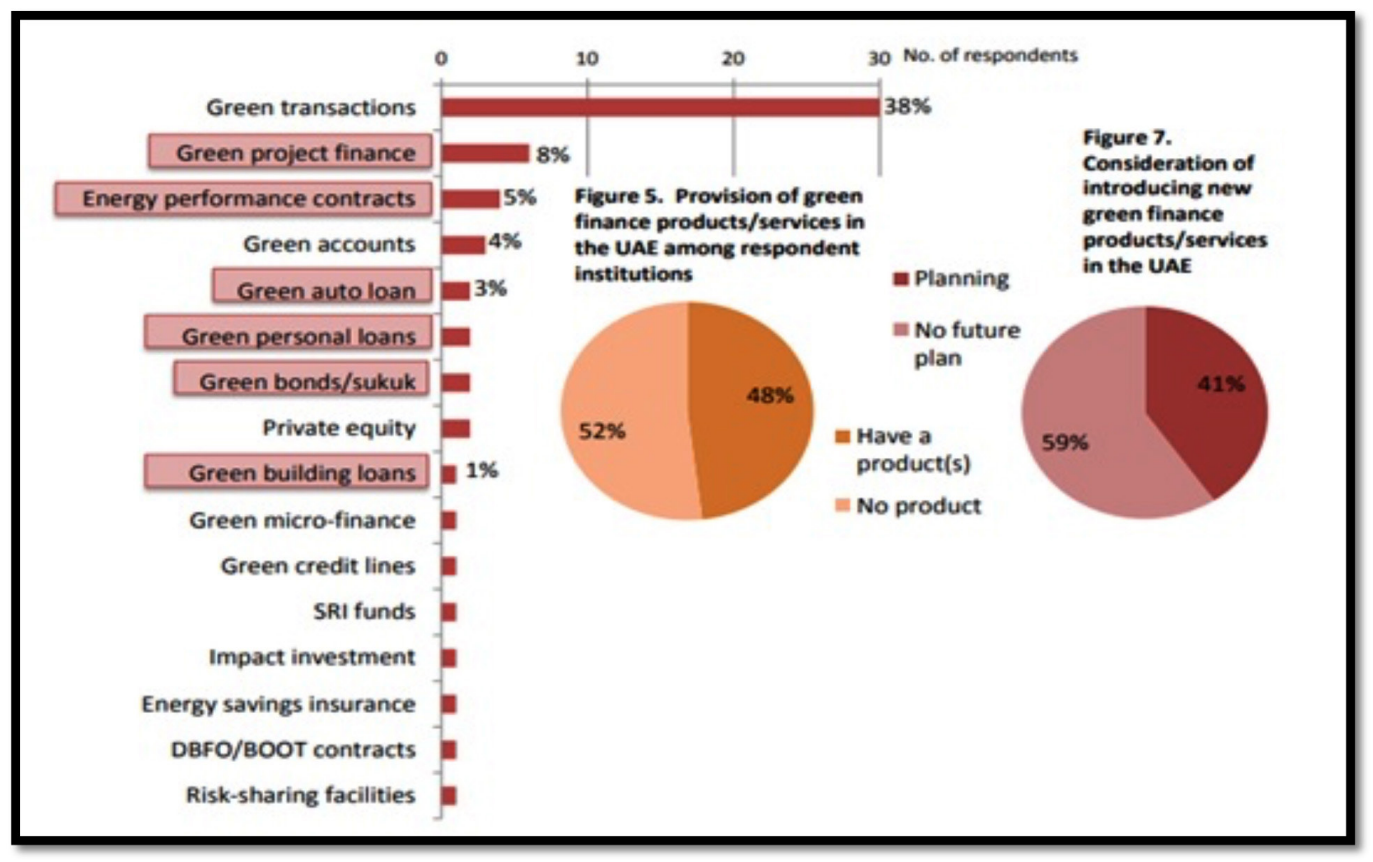

Figure 1: Adoption level of green banking products and services in the UAE. Source: (UAE Ministry of Environment and Water, 2016)

facing consumers wanting to use GB products and services. In a report Iqbal et al. (2018) attempted to study the factors influencing the customer's adoption of GB products and services in Bangladesh.

By conducting a primary survey using the Unified Theory of Acceptance and Use of Technology (UTAUT), they found that timeliness, facilitating conditions, environmental concerns, effort expectancy and performance expectancy, significantly affect the customers' perceptions of GB. In another quantitative study, Iqbal et al. (2017) looked at service quality and other variables that affected clients' behaviour and intentions towards GB.

The survey reported that reliability, privacy, responsiveness, empathy, and information quality affect performance expectancy. In the meantime, performance expectancy, effort expectancy, and facilitating conditions significantly affected the consumers' intention to use GB products and services.
Yet another recent study broadly based on literature review extended the UTAUT model stating that the integration of religion is an important determinant for the capture of Islamic banking customers in the UAE and ensuring they adopt GB products and services (Bouteraa et al., 2020b).

As far as a critical literature review is concerned, there is a comprehensive agreement among researchers about the lack of available literature on GB. The literature does not fully explain the barriers to the adoption of GB products and services and requires further investigation (Sahoo et al., 2016; Iqbal et al., 2018; Uddin \& Ahmmed, 2018; Bukhari et al., 2019; Julia \& Kassim, 2019; Bouteraa et al., 2020a, 2020b). Furthermore, all the previous papers on GB adoption rates were based on descriptive statistics. To date, no study has been done to qualitatively explore the determinants of GB adoption, which is the appropriate approach to take when there is limited data available and there is difficulty in identifying the determining 
factors of a specific phenomenon (Creswell, 2012; Creswell, 2013).

Although GB adoption rates are increasing in the UAE, research remains inadequate. Shaumya and Arulrajah (2017) note that the majority of studies regarding GB, in general, have been found in the United States (US), Europe, China, India, and Bangladesh, but not the in UAE(www.scopus.com, 2019). Yet, the UAE-MoEW (2016) has demanded that academicians and experts conduct more comprehensive research to positively influence consumers' behaviour toward GB. This presents a critical gap regarding GB in general and GB adoption in particular.

This study is motivated to fill in the gap by empirically exploring the determinants of bank customers' intention to adopt GB. In other words, this research aims to narrow the gap between theory and practice regarding bank customers' intention to adopt GB by answering the following question: what are the determinants of the bank customers' intention to adopt GB products and services?

\section{Concept of Green Banking Vs. Traditional Banking}

Traditional banking is the financial intermediary whose principal function is to collect, retain, and lend capital to clients. They provide customers with numerous facilities such as opening accounts, transferring and lending funds, clearing checks, and clearing demand drafts. The principal objective of traditional banking is to improve its financial leverage by increasing income without taking into consideration the adverse economic and environmental effects of its operations.

Traditional banking schemes require clients to visit bank branches to conduct their financial transactions during clearly defined working hours only. This takes a lot of the customers' time and effort as it not only entails driving to the bank but also waiting in lengthy queues to conduct their transactions. Traditional banking often requires a paper-based processes to conduct a financial transactions, which leads to deforestation and damages the climate.

Also, it needs a lot of human resources and costly expenses when it comes to building up a new market system or growing operations.

On the contrary, GB is an inclusive bank activity taken to signify beyond profit-making, which includes improving welfare. It builds social equity, whereas reducing ecological risks by inter-linking economic, environmental, and social considerations to accomplish sustainable development (Bouteraa et al., 2020a). It allows banks to perform environmentally friendly financial transactions by integrating their organisational upgrades with technology. The green banks must diligently check that the transactions of the customer comply with all the legal and environmental compliances as any failure can lead to the banks holding ineffective assets.

Green Banking mostly refers to the financial products and services that make extensive use of Information Technology systems, paperless financial transactions. It offers access to banking services 24/7 like e-banking, SMS banking, mobile banking, e-statements, the online opening of bank accounts, e-payment, e-investment, the use Automated Teller Machiens (ATM), e-Fund Transfer Network and further mobile monetary services in the form of e-currency (Choudhury et al., 2013; Masukujjaman \& Aktar, 2014).

Green banks aim to protect the natural environment, improve social welfare, and deliver an alternative to conventional financial services with reliable and efficient services, durable protection and efficiency at reduced cost rates for banks and stakeholders equally.

\section{Theoretical Framework}

Following the introduction of the green banking initiatives in the UAE financial institution, have embraced environmentally sustainable banking policies through the extensive usage of renewable resources and technology, commonly known as the GB. 
Since green technology forms the foundation of GB, it is essential to comprehend individual acceptance and use of this type of technology under the information systems research. The UTAUT model designed by Venkatesh et al. (2003) has been used as a baseline model to test a range of behavioural intentions around the use of technology in the individual settings. The original UTAUT model is framed with four essential determinants for the adoption and use of IT, namely: performance expectancy, effort expectancy, social influence, and facilitating conditions. Additionally the test has up to four moderators of key relationships that are gender, age, experience, and voluntariness of use.

The UTAUT model has proved to be reliable in explaining up to $70 \%$ of the variance in individual behaviours and intentions (Venkatesh et al., 2003). Interestingly, the UTAUT model has also been confirmed to be a robust model to capturean individual's adoption behaviour in the context of GB studies show (e.g., Rifat et al., 2017; Iqbal et al., 2018; 2019; Bouteraa et al., 2020b); however, it has not been widely used in GB adoption studies. Venkatesh et al., (2012) further argued that the rational introduction of additional constructs could expand the UTAUT 's theoretical horizons.

Against this backdrop, this study has selected the UTAUT model as a theoretical basis for developing its research model. The principal objective of this study is not to replicate the UTAUT model, but to explore additional influences that can significantly affect the bank customers' intent to adopt GB products and services in an emerging market context.

\section{Research Methodology}

The qualitative approach is the most appropriate when limited data is available and there is a necessity for an exploration arising from the difficulty of identifying the determining factor of a specific phenomenon (Creswell, 2012; Creswell, 2013). Qualitative investigations are not used to generate generalisability of the conclusions, but to select sites and participants who have information, which would help researchers better understand the phenomenon being studied (Creswell, 2012; Creswell \& Poth, 2018;). As a result of the limited amount of available literature and other investigative material, as mentioned earlier, this study has employed the qualitative method to explore the determining factors behind a bank customers' intent to adopt GB products and services.

The choice of a certain sampling technique in the qualitative approach depends on its suitability to the research questions and the research objectives (Creswell, 2012; Creswell \& Poth, 2018). The focus group sampling technique allows the researcher to select the participants based on their relevance and relationship to the topic under study (Creswell, 2012; Creswell \& Poth, 2018).

For this study, a focus group sampling technique was used to identify the appropriate informants. Here, participants were selected based on their professional experience in the banking industry and their position and expertise in dealing with bank customers, which is the focus area of this research paper.

Regarding the number of interviewees, Steinar (1996) suggests a range of between five and 25 interviewees is considered sufficient for conducting qualitative interviews. However, recent qualitative studies have mentioned that the subjective assessment of the researcher determines the sample size, when he/she realises that the point of saturation has been reached (Guba \& Lincoln, 1994; Creswell, 2012; Creswell \& Poth, 2018;).

The theoretical saturation was employed to determine the final sample size (Creswell \& Poth, 2018). Accordingly, this researcher invited ten bank professionals from different levels to participate in the semi-structured interview, which was a sufficient number to reach the saturation point in this study. The semistructured interviews were conducted between December 2019 and March 2020.

According to Jeyaraj et al. (2006), the challenges facing adoptive behaviours, in 
general, are mainly related to four generic categories namely: individual factors, innovative factors, organisational factors and environmental factors. In keeping with the findings in Jeyaraj et al. (2006), the paradigm used to develop the interview protocol instruments was based on the main themes of a conceptual framework, which was primarily related to the four generic categories mentioned earlier. This researcher also consulted and worked with experts and academicians of the qualitative approach to ensure the proper development of the interview questions (Creswell, 2012; Creswell \& Poth, 2018).

The current study analysed the data using the Thematic Content Analysis (TCA) technique on NVivo 11 Plus software following a strategy suggested by Braun and Clarke (2006), which involves a constant movement back and forth between the entire data set, coded extracts and the analysis of the produced data.

The first step was getting familiar with the data, in which all the data was transcribed and translated into English. The second step was generating the initial codes. The third step was searching for related themes. Next, all the coded items were separated into four main themes namely, individual, technology, organisation, and environmental.

Afterwards, the themes, and all the coded items were reviewed again and a check of the date by peers was also done at this time. The sixth step was defining and naming the items. Then, the new items were submitted to an expert panel for final evaluation (Braun \& Clarke, 2006).

Table 1: Participants' Demographic Information

\begin{tabular}{|c|c|c|c|c|c|}
\hline $\begin{array}{c}\text { Serial } \\
\text { Number } \\
\text { Participants }\end{array}$ & Bank Name & Current position & $\begin{array}{c}\text { Working } \\
\text { Experience in } \\
\text { the Current } \\
\text { Position }\end{array}$ & $\begin{array}{c}\text { Working } \\
\text { Experience in } \\
\text { the Current } \\
\text { Bank }\end{array}$ & $\begin{array}{c}\text { Highest } \\
\text { Qualification }\end{array}$ \\
\hline P1 & $\begin{array}{c}\text { Dubai Islamic } \\
\text { Bank }\end{array}$ & Head of Branch & 3 years & 8 years & MBA Finance \\
\hline $\mathrm{P} 2$ & $\begin{array}{c}\text { Abu Dhabi } \\
\text { Bank }\end{array}$ & Head of Branch & 2 years & 7 years & MBA Finance \\
\hline P3 & $\begin{array}{l}\text { Abu Dhabi } \\
\text { Islamic Bank }\end{array}$ & Head of Branch & 4 years & 10 years & MBA Finance \\
\hline P4 & Noor Bank & Head of Branch & 2 years & 7 years & $\begin{array}{c}\text { MSC Finance } \\
\text { and Banking }\end{array}$ \\
\hline P5 & $\begin{array}{l}\text { Abu Dhabi } \\
\text { Bank }\end{array}$ & Regional Manager & 1 year & 12 years & MBA Finance \\
\hline P6 & Emirates Bank & $\begin{array}{c}\text { Head of the } \\
\text { Strategic Planning } \\
\text { Unit }\end{array}$ & 2 years & 8 years & $\begin{array}{c}\text { PhD. Business } \\
\text { Management }\end{array}$ \\
\hline P7 & Emirates Bank & $\begin{array}{l}\text { Assistant General } \\
\text { Manager }\end{array}$ & 2 years & 9 years & $\begin{array}{c}\text { MSC Business } \\
\text { Management }\end{array}$ \\
\hline P8 & $\begin{array}{c}\text { Dubai Islamic } \\
\text { Bank }\end{array}$ & $\begin{array}{l}\text { Sales Executive } \\
\text { Manager }\end{array}$ & 3 years & 16 years & $\begin{array}{l}\text { DBA } \\
\text { International } \\
\text { Business }\end{array}$ \\
\hline P9 & Sharjah Bank & $\begin{array}{l}\text { Marketing } \\
\text { Manager }\end{array}$ & 2 years & 9 years & $\begin{array}{c}\text { MSC Business } \\
\text { Management }\end{array}$ \\
\hline P10 & Sharjah IBank & Sales Manager & 3 years & 10 years & MBA Finance \\
\hline
\end{tabular}




\section{Interview Findings and Discussion}

The interpretation and description of the research findings for factors that determine a customers' intent to adopt GB products and services are categorised under four generic categories (themes) as mentioned eralier and outlined by Jeyaraj et al. (2006).

The most critical determinants (subthemes) are proved by using direct quotes from the bank professionals who participated in the semi-structured interview.

The ten participants were denoted in the table as P1 -P10 to preserve the anonymity of their identity. Table 1 reveals the demographic information of the participants involved in the present study.

\section{Individual Factors}

The interviewees reported several individual factors that are expected to influence their customers' behaviour towards the use of GB.

However, "Awareness" "Personal Innovativeness" and "Perceived Benefit" were the most frequent determinants, as summarised in Table 2.

The following section is mainly based on these direct quotes, which include significant content.

The data reveals that awareness determines the customers' intention to make their green financial transactions. Some, $80 \%$ of interviewees agreed that awareness is an essential individual factor influencing their customers' behaviour towards the adoption of GB.
Awareness refers to the consumers' amount of information about a specific product or service and the levels of consciousness on the existence, concept, purpose, and benefits (Hanafizadeh \& Khedmatgozar, 2012; Selevičienè \& Burkšaitiene, 2015; Ratanya, 2017). Many interviewees stressed that the lack of awareness among customers regarding the availability and benefits of GB products and services leads to low adoption rates as reported by most bank professionals:

P1-: "I am quite sure that the main reason is the lack of information and lack of awareness; the bank clients do not have any basic idea about green banking's benefits."

P2-: “Awareness! It's the absence of awareness. Awareness is the main reason. Our people in the UAE do not know the value of green products; they do not know it is cheaper for long term calculation, more convenient and healthier for the individual and society than the conventional. You know people are the enemies of what they do not know".

P3-: "Our customers do not know what green banking is! or why it is important!"

P4-: "The biggest issue is we think we have to make people understand what we have and what it is."

P5-: "Another important thing is customer awareness. Most of the customers do not know green banking; some people say the banks' activity does not affect the environment; it is already eco-friendly. So, what is green banking?".

Table 2:Individual determinants extracted from the interviews

\begin{tabular}{|c|c|c|c|c|c|c|c|c|c|c|c|c|}
\hline \multirow{2}{*}{$\begin{array}{l}\text { Individual } \\
\text { Factors } \\
\text { Extracted }\end{array}$} & \multicolumn{10}{|c|}{ Participants } & \multirow[b]{2}{*}{$\begin{array}{c}\text { Total } \\
\text { participants }\end{array}$} & \multirow[b]{2}{*}{ Total (\%) } \\
\hline & P1 & P2 & $\mathbf{P 3}$ & P4 & P5 & P6 & P7 & P8 & P9 & P10 & & \\
\hline Awareness & $\sqrt{ }$ & $\sqrt{ }$ & $\sqrt{ }$ & $\sqrt{ }$ & $\sqrt{ }$ & $\sqrt{ }$ & $\sqrt{ }$ & $\sqrt{ }$ & & & 08 & $80 \%$ \\
\hline $\begin{array}{l}\text { Personal } \\
\text { Innovativness }\end{array}$ & $\sqrt{ }$ & $\sqrt{ }$ & $\sqrt{ }$ & & $\sqrt{ }$ & & $\sqrt{ }$ & $\sqrt{ }$ & $\sqrt{ }$ & & 07 & $70 \%$ \\
\hline $\begin{array}{l}\text { Perceived } \\
\text { Benefit }\end{array}$ & $\sqrt{ }$ & $\sqrt{ }$ & $\sqrt{ }$ & & & $\sqrt{ }$ & $\sqrt{ }$ & $\sqrt{ }$ & & & 07 & $70 \%$ \\
\hline
\end{tabular}


P6-: "Definitely, if the clients have enough information about the benefits of green banking, they definitely will switch to green."

P7-: "Ican say that the majority of the clients are unfamiliar with concepts and mechanisms of green banking and its benefits for them and for the bank itself which make the demands on these products very low."

P8-: "Our customers do not have information about green products."

Individual innovativeness such as personality traits might restrict him/her form trying new products and adopting new technologies as it will require him/her to change the usual work routines and the risk of failure or loss due to the switch to those new green products, this view was shared by $70 \%$ of the respondents interviewed.

Personal Innovativeness can be defined as the individual's propensity and willingness to explore and examine new things such as new technologies and innovations (Agarwal \& Prasad, 1998). As stated by many participants:

P1-: "The clients are not willing to change to new products which are not yet eminent in the market, but they keep demanding the old, known, and successful products."

P2-: "We can notice some unwillingness due to limited successful green models in the country, they do not want to simply switch to another product or green project financing which is yet unfamiliar to the market."

P3-: "Our clients are not open to adopting a new product or new technology. They feel satisfied with what we offered for them before. Especially retail customers and the private sector".

P5-: "It is hard for the customers' to transform their behaviour to new products or transactions named green banking."

P7-: "they keep demanding the conventional banking transactions that have been operating for decades and is already rooted in the mind of our consumers, but not green."

P8-: "Our people still have the inclination to conventional financial, not the green transactions because this is their comfort zone and no complexity."

P9- "I see that the main obstacle is that the absence of customers' innovative mindset."

Furthermore, the use of probing techniques with the interviewees helped to extract more information from them and to get a clearer picture of the research issue. The next factor, that of the perceived benefit from the green banking products, which was also mentioned by $70 \%$ of the respondents, was perceived to be a barrier to the adoption of GB by customers.

A perceived benefit is the client's selection of a specific product that comprises a cognitive and affective assessment of usefulness and self-indulgent profits (Lee et al., 2007), in addition to the evaluation of products value by comparing the anticipated advantage and perceived sacrifices (Akturan \& Tezcan, 2012) and analyzed by structural equation modeling (SEM.

In the interviewee's words:

P1-: "Most of the customers consider their expected financial benefit from the transaction, yes, most of them only ask how much they pay and how long and what is the interest rate. What I want to say is that the expected benefit which decides the nature of the products either green or not".

P2-: "Our private customers do not want to be the initiators to use the new green banking products due to the uncertainty of the financial revenue."

P3-: "Our customers seek only to maximise their profit. They would go for whatever more profitable and multiply the income, regardless of the negative effect on the environment." 
P6-: "The customers only consider their expected financial profit from the transaction."

P7-: "They just want to get loans that benefit their private business. ...they think based on profitable perspectives".

P8-: "Profit increase is the main and the first concern of the clients."

\section{Organisation Factors}

The organisational characteristics are attributes derived from the management strategy and the organisation's corporate values (Magnier \& Senoo, 2008). The informants stated that numerous organisational factors were likely to influence a customers' behaviour towards the use of GB. The majority of participants insisted on two essential elements namely: "System Quality" and "Top Management Support" as presented in Table 3.

The subsequent section is primarily based on discussion and the direct quotes of the interviewees.

Green system quality was frequently expressed by $60 \%$ of respondents as an essential organisational issue. It should be developed in a way that takes into consideration the policy, response time, system reliability, system availability, functionality and compatibility with all categories of customers projects' because continuing with the current system quality style will discourage customers from adopting GB products and services.
In this regard many of the participants in the semi-structured interview said:

P1-: "I think the time-consuming and long process and complex new regulations either by bank management or government as well should be an obstacle for customers to go green.... green banking somehow limits the nature of business. That why it is not always compatible with the clients' vision".

P2-: "Some green products like the green financing project, green housing loan, energy-efficient financing projects, ... the process is too long because the client needs to go through many steps and have to meet many conditions to provide the green compliant, especially for manufacturing industries...too many documents, too many endorsements, and this make the green banking unfavourite for the client and unlikely to go green".

P3-: "Green banking does not have a variety of products that are compatible with all customers' needs, which makes the customers prefer conventional products."

P4-: "People are ina hurryto sign the documents and deadlines. The transaction may take 24 to 30 months for the transaction from the initial term sheet with our contracts to the final stage to execute the project and is ready to close; it's a very long process".

P5-: "The long process and the complex procedure and plentiful of documents required to meet the green loan condition and in some green products will definitely lead to slow acceptance by the customer."

Table 3: Organasation determinants extracted from the interviews

\begin{tabular}{|c|c|c|c|c|c|c|c|c|c|c|c|c|}
\hline \multirow{2}{*}{$\begin{array}{l}\text { Organisation } \\
\text { Factors } \\
\text { Extracted }\end{array}$} & \multicolumn{10}{|c|}{ Participants } & \multirow[b]{2}{*}{$\begin{array}{c}\text { Total } \\
\text { participants }\end{array}$} & \multirow[b]{2}{*}{ Total (\%) } \\
\hline & P1 & $\mathbf{P 2}$ & P3 & P4 & P5 & P6 & P7 & P8 & P9 & P10 & & \\
\hline $\begin{array}{l}\text { System } \\
\text { Quality }\end{array}$ & $\sqrt{ }$ & $\sqrt{ }$ & $\sqrt{ }$ & $\sqrt{ }$ & $\sqrt{ }$ & & & $\sqrt{ }$ & & & 06 & $60 \%$ \\
\hline $\begin{array}{l}\text { Top } \\
\text { Management } \\
\text { Support }\end{array}$ & $\sqrt{ }$ & $\sqrt{ }$ & $\sqrt{ }$ & $\sqrt{ }$ & & $\sqrt{ }$ & $\sqrt{ }$ & & & $\sqrt{ }$ & 07 & $70 \%$ \\
\hline
\end{tabular}


P8-: "The issue is in the green product quality itself and the variety of green products that the bank is offering to its customers to meet the needs."

Furthermore, $70 \%$ of the participants blamed the bank's top management for not accurately adapting to the new GB mechanisms and hesitating to transform the bank's infrastructure due to a lack of experience with regards to innovation.

Additionally, the participants said that the lack of a lead managerial role with the proper professional qualifications meant that banks are unable to provide a comprehensive standard framework mechanism for GB.

This they say will make the bank incapable of promoting GB products and services and fulfilling its GB ambitions. The banks will also not be able to improve the currently low GB adoption rates.

Meanwhile, top management support refers to the extent of provision, commitment, and energetic engagement of the senior management regarding the planning and implementation of new GB systems. This could be a barrier against the adoption of GB as those managers do not realise the actual needs and requirements for the implementation of this innovative mechanism. The following statements confirm that the top management support could be considered a source of intimidation.

P1-: "It is hard for our marketing team to promote $G B$ due to absence of clear and standard model and framework that explains all the process from the business idea until the execution and launching of the project, And this clear model is very important in convincing the client to switch or adopt green banking."

P2-: "Until the present, there is no comprehensive standard framework that covers the financial and legal aspects to be executed for all the projects equally, but we have to refer to them for every project, especially for large financing green projects. And this will create some uncertainty and unwillingness for the private client".

P3-: "We need to improve our marketing and sales strategy and focus more on promoting green banking in a better innovative approach to attract the private sector."

P4-: "Well, the infrastructure of the bank, I think it is number one, the transformation of the bank towards all these renewable projects. I think it is pretty heavy. .... still, we do not know what we are trying shift for".

P6-: "The green project financing applicant mostly deny or switch to the regular project financing due to offensive and tough regulation by the bank management."

P7-: "It is therefore imperative for the bank to design informative and effective advertising movements about green banking."

P10-: "The bank management is still under discussion concerning this matter, as they have to meet many government and shareholders expectations, afraid of failure or loss to transform the bank policy which may affect the bank performance."

\section{Innovative Factors}

Innovative factors refer to the characteristics that describe technology (Jeyaraj et al., 2006). The frequent technological contributor to the phenomenon being studied, as expressed by $60 \%$ of interviewees was the worry and the concern about the security and privacy of the customers' data being compromised (See Table 4).

Customer perception of less protection, privacy and the fear of illegitimate penetration by way of cyber attack stands as an obstacle. It makes the adoption of GB an intimidating and unapproachable option for the bank customers.

Technology is the foundation of GB products and services. Therefore, there is a need to set a reliable, robust and up-to-date security system to prohibit any unauthorised access or misuse of the customers' private data as well as guarantee 
the safety of the financial transaction. This factor of converning the security and privacy of the transactions and customer data is mentioned repetitively by $60 \%$ of the participants:

P1-: "In some GB products like e-banking and e-Statement, online purchase ... the client may feel less secure. Especially when technology deals in a direct way with the money where the customer must deliver his/her correct data like full name altogether with the credit card number and phone number... which is part of privacy".

P2-: "In general, our people in the UAE are quite sensitive when technology has direct interaction with money.... The client feels less secure”.

P3-: "Someclientsfeelriskywithe-transactions, especially with large amounts of money.... You know, recently, many hackers get access to their privacy and accounts. In fact, we have many cases that happened in many banks in the UAE”.

P4-: "They feel less confident; they are moving very slow."

P5-: "The technology-related green products are not always safe, which makes the customers feel that their privacy is exposed in a kind of risk or illegal penetration."
P10-: "It has some access to client privacy; it makes them unsafe. Even we offer a very high secured banking system".

\section{Environment Factors}

Environment or external factors comprise a range of issues outside the bank; over which it does not have much control. In the direction of investigating the environmental determinants, the interviewer used probing techniques and secondary questions.

The bank professionals mentioned several external factors that influenced the customers' use of GB. There is a broad agreement among the participants on two central factors, namely: "government support" and "vendor support" as demonstrated in Table 5.

The shortage of government support was also highlighted as a key external factor by $70 \%$ of the interviewees, as this factor affected the adoption of the GB by both banks and customers.

Government support refers to the role of the government-related policies that cover the rules or promotion programmes for GB, which will ultimately result in the customers' adoption of GB products and services. The Finance Ministry, the central bank and the banks' own policy-makers are the entities responsible

Table 4: Innovative determinants extracted from the interviews

\begin{tabular}{|c|c|c|c|c|c|c|c|c|c|c|c|c|}
\hline \multirow{2}{*}{$\begin{array}{l}\text { Innovative } \\
\text { Factor } \\
\text { Extracted }\end{array}$} & \multicolumn{10}{|c|}{ Participants } & \multirow[b]{2}{*}{$\begin{array}{c}\text { Total } \\
\text { participants }\end{array}$} & \multirow[b]{2}{*}{ Total $(\%)$} \\
\hline & P1 & $\mathbf{P 2}$ & P3 & P4 & P5 & P6 & P7 & P8 & P9 & P10 & & \\
\hline $\begin{array}{l}\text { Privacy \& } \\
\text { Security }\end{array}$ & $\sqrt{ }$ & $\sqrt{ }$ & $\sqrt{ }$ & $\sqrt{ }$ & $\sqrt{ }$ & & & & & $\sqrt{ }$ & 06 & $60 \%$ \\
\hline
\end{tabular}

Table 5: Environment determinants extracted from the interviews

\begin{tabular}{|c|c|c|c|c|c|c|c|c|c|c|c|c|}
\hline \multirow{2}{*}{$\begin{array}{l}\text { Environment } \\
\text { Factors } \\
\text { Extracted }\end{array}$} & \multirow[b]{2}{*}{ P1 } & \multirow[b]{2}{*}{$\mathbf{P 2}$} & \multirow[b]{2}{*}{ P3 } & \multirow[b]{2}{*}{ P4 } & \multicolumn{6}{|c|}{ Participants } & \multirow[b]{2}{*}{$\begin{array}{c}\text { Total } \\
\text { participants }\end{array}$} & \multirow[b]{2}{*}{ Total (\%) } \\
\hline & & & & & P5 & P6 & P7 & P8 & P9 & P10 & & \\
\hline $\begin{array}{l}\text { Government } \\
\text { Support }\end{array}$ & $\sqrt{ }$ & & & $\sqrt{ }$ & $\sqrt{ }$ & $\sqrt{ }$ & & $\sqrt{ }$ & $\sqrt{ }$ & $\sqrt{ }$ & 07 & $70 \%$ \\
\hline Vendor Support & $\sqrt{ }$ & $\sqrt{ }$ & $\sqrt{ }$ & $\sqrt{ }$ & & $\sqrt{ }$ & & $\sqrt{ }$ & & & 06 & $60 \%$ \\
\hline
\end{tabular}


for the regulation and governance of GB, the regulations that they decide to put in place could make or break GB adoption rates. The direct quotes from the bank professionals interviewed explain this further:

P1-: "Government regulation is a little offensive and complicated. They make the client run away from the green project by creating new procedures and approval from many organisations and laboratories and diving deep in documents to approve the project".

P4-: “We spent a lot of money and time to get into that market spot, but we have not given up on, and accidentally moved on due to lack of connecting with authorities' relationships."

P5-: "Well, the government regulations are not always consistent with the green bank's vision."

P6-: "The green project financing applicant mostly deny or switch to the regular project financing due to offensive and tough regulation by the bank management as well as the government requirements."

P8-: "In fact, many real estate agents and promoters gave up due to complex government law."

P9-: "The government has imposed tough conditions and principles for the customer to meet the requirement of green financing."

P10- "This combination of tough regulations come from the management of the bank, the central bank, as well as the country governors, are also blamed for the slow acceptance of $G B$."

Vendor Support is one of the issues was raised by $60 \%$ of participants that is related neither to the bank or the customers. Vendor support is the backing that a corporate acquires from external bases of technical expertise (Premkumar \& Roberts, 1999).

The lack of support of some private supply companies and the merchants' low experience in the field of green banking is considered a challenge for the implementation of green projects and the promotion of GB products and services. This was recognised by the interviewees as one of the crucial external barriers that discouraged the use of GB by customers, particularly green project financing applicants:

P1-: "For project financing like efficient and clean energy financing project requires very sophisticated machines and equipment which are not available in our local market in the UAE."

P2-: "our local vendors and suppliers still offering the conventional and non-green products that satisfy the demand of their customers. That is why we do not receive many efficient and eco-friendly projects financing applications".

P3-: "Also, the vendors and suppliers do not expose their green products to the clients; and we as bankers, we do not sell the ultimate product, but we only finance them."

P4-: "The issue starts with the vendor, not from the banks in certain products."

P6-: "We have a limited green project and clean energy supply in the local market because the suppliers are not aware of go green mechanism as well."

P8-: "The vendors are not recommending the green products to the customers."

\section{Conceptual Model of Study}

Figure 2 portrays the study's conceptual model. The UTAUT model forms the backbone theoretical framework for this study. Additional factors representing other critical dimensions have been added to the original UTAUT model from the qualitative investigation to improve its performance regarding explaining the customers' intention behaviour towards using GB. 


\section{Conclusion and Implication}

The main objective of this study is to develop a conceptual model for bank customers' intent to adopt GB products and services, drawing on the UTAUT model. Specifically, the purpose is to explore the determining factors and barriers to a bank customers' intent to adopt GB practices as this is an issue of concern towards attaining sustainability.

In order to make an in-depth investigation of those barriers and to have a rich understanding of the situation, the study employed a qualitative approach using semi-structured interviews to attain the study's objective.

Reviewing the views of various bank experts from multiple platforms helps to get a realistic and objective image of the phenomenon from different perspectives. From the analysis of the semi-structured interview, the researchers were able to confirm the low adoption of GB products and services among the bank customers in the UAE, which supports previous findings by the MoEW (2016). The output of the TCA identified eight new insights of the bank customers' intention to adopt GB grouped under four main categories, "i.e., individual, organisational, innovative, and environmental" as displayed in Figure 2.

The research contributes to the current literature of customers GB adoption by providing an additional understanding of the current issue by three factors that reflect the individual attributes that are awareness, personal innovativeness, and perceived benefit. Two factors describe the organisation's characteristics, namely green system quality and the top management support. Meanwhile,

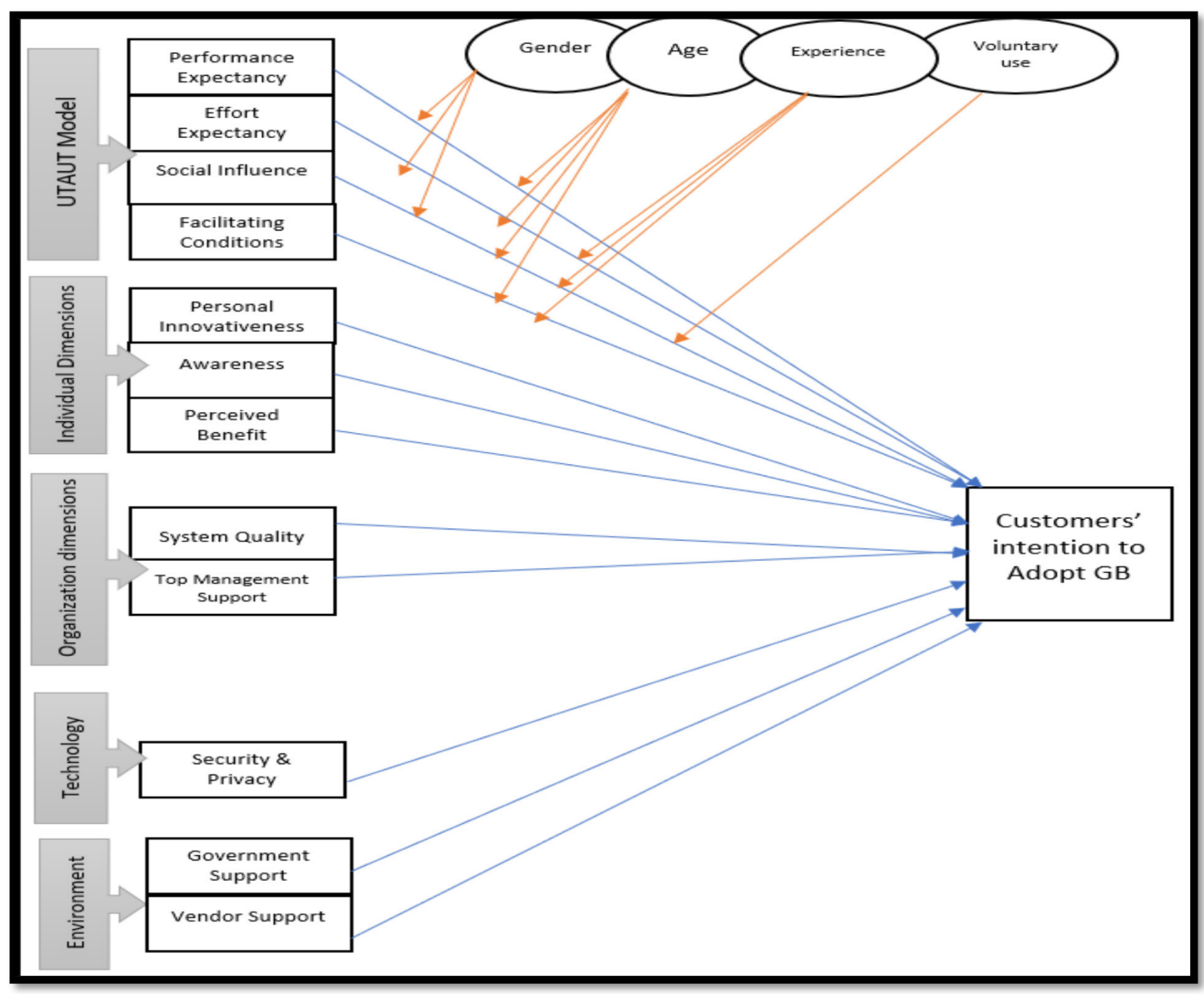

Figure 2: The proposed model of study

Source: Developed by the Authors 
privacy and security is the single factor related to technology. Lastly, government support and vendor support were identified as external environmental issues.

This study developed a rational choice model for GB adoption. Theoretically, the study extended the existing literature by incorporating eight new constructs to the original UTAUT model to empower scholars and researchers to recognise the drivers of customers' intention to adopt GB.

Practically, this study guides policymakers, decision-makers, central bank, and banks' marketing managers by providing a better understanding of the actual issues and challenges that are facing their customers.

To design the proper programmes to increase GB adoption that would drive the principles of sustainability, environmental protection, and socio-economic development.

From a methodological point of view, the explorative qualitative design of the study allowed the researcher to offer a more comprehensive explanation of the barriers to adoption faced by the customers.

\section{Limitations and Future Research Directions}

Overall, studies of GB adoption are still limited and need further investigations. This study has a few limitations. First, the conclusions drawn from this investigation are based solely upon the qualitative inquiry, upcoming research can examine the behavioural intent based on a quantitative survey for further validation and generalisation of the conclusions.

Other than the factors suggested in this study, there can be additional factors that can influence a consumers' acceptance of GB products and services. Future researchers might study religion as a personal value dimension since Islam is the official religion in the UAE, and it is an essential concern for Muslim majority communities in general (Bouteraa \& Al-Aidaros, 2020). This can enhance the understanding of more precise determinants for GB adoption in the UAE.
Finally, the researchers recommend conducting similar investigations within the different geographic contexts and specific banking sector.

\section{Acknowledgements}

This research has been self-funded. This research is part of a dissertation which was submitted as partial fulfilment to meet requirements for the degree of Doctor of Philosophy at Islamic Business School (IBS), College of Business (COB), Universiti Utara Malaysia (UUM).

\section{References}

Agarwal, R., \& Prasad, J. (1998). A conceptual and operational definition of personal innovativeness in the domain of information technology. Information Systems Research, 9(2), 204-215.

Akturan, U., \& Tezcan, N. (2012). Mobile banking adoption of the youth market. Marketing Intelligence \& Planning, 30(4), 444-459. https://doi. org/10.1108/02634501211231928

Bouteraa, M. (2020). Descriptive approach of green banking in the United Arab Emirates (UAE). IBMRD's Journal of Management \& Research, 9(1), 1-9. https://doi. org/10.17697/ibmrd/2020/v9i1/152324

Bouteraa, M., \& Al-Aidaros, A.-H. (2020). The role of attitude as mediator in the intention to have Islamic will. International Journal of Advanced Research in Economics and Finance, 2(1), 22-37.

Bouteraa, M., Raja Hisham, R. R. I., \& Zainol, Z. (2020a). Green banking practices from Islamic and Western perspectives. International Journal of Business, Economics and Law, 21(5), 1-11.

Bouteraa, M., Raja Hisham, R. R. I., \& Zainol, Z. (2020b). Islamic banks customers, intention to adopt green banking: Extension of UTAUT Model. International Journal of Business and Technology Management, 
2(1), 121-136. http://myjms.moe.gov.my/ index.php/ijbtm

Braun, V., \& Clarke, V. (2006). Using thematic analysis in psychology. Qualitative Research in Psychology, 3(2), 77-101. https://doi. org/10.1017/CBO9781107415324.004

Bukhari, S. A. A., Hashim, F., Amran, A. Bin, \& Hyder, K. (2019). Green banking and Islam: Two sides of the same coin. Journal of Islamic Marketing, ahead-of-p(aheadof-print). https://doi.org/10.1108/JIMA-092018-0154

Choudhury, T. T., Salim, M., Mamoon, M., Bashir, A., \& Saha, P. (2013). Influence of stakeholders in developing green banking products in Bangladesh. Research Journal of Finance and Accounting, 4(7), 67-77.

Creswell., \& Poth, C. (2018). Qualitative inquiry \& research design choosing among five approaches $\left(4^{\text {th }}\right.$ ed.). Thousand Oaks, California 91320: Sage Publications.

Creswell, J. (2012). Educational research planning conducting and evaluating quantitative and Qualitative Research (4th ed.). Boston: Pearson Education.

Creswell, J. W. (2012). Qualitative inquiry and research design: Choosing among five approaches. London: SAGE.

Government.ae. (2018). Environmental challenges. Retrieved October 20, 2018, from https://www.government.ae/en/ information-and-services/environmentand-energy/environmental-challenges-inthe-uae

Grove, S. J., Fisk, R. P., Pickett, G. M., \& Kangun, N. (1996). Going green in the service sector. European Journal of Marketing, 30(5), 56-66. https://doi. org/10.1108/03090569610118777

Guba, E. G., \& Lincoln, Y. S. (1994). Competing paradigms in qualitative research. In E. N. K. Denzin \& Y. S. Lincoln (Eds.), Handbook of qualitative research. Thousand Oaks, CA: Sage.
Hanafizadeh, P., \& Khedmatgozar, H. R. (2012). The mediating role of the dimensions of the perceived risk in the effect of customers' awareness on the adoption of Internet banking in Iran. Electronic Commerce Research, 12(2), 151-175. https://doi. org/10.1007/s10660-012-9090-Z

Iqbal, M., Nisha, N., \& Raza, S. (2017). Customers' perceptions of green banking: Examining service quality dimensions in Bangladesh. In P. Ordóñez de Pablos (Ed.), Managerial strategies and solutions for business success in Asia (1st ed.). (pp.1-20).

Iqbal, M., Nisha, N., \& Raza, S. (2019). Customers' perceptions of green banking: Examining service quality dimensions in Bangladesh. In Green business: Concepts, methodologies, tools, and applications. IGI Global.

Iqbal, M., Nisha, N., Rifat, A., \& Panda, P. (2018). Exploring client perceptions and intentions in emerging economies: The case of green banking technology. International Journal of Asian Business and Information Management, 9(3), 14-34. https://doi. org/10.4018/IJABIM.2018070102

Jeyaraj, A., Rottman, J. W., \& Lacity, M. C. (2006). A review of the predictors, linkages, and biases in IT Innovation Adoption Research. Journal of Information Technology, 21(1), 1-23. https://doi. org/10.1057/palgrave.jit.2000056

Julia, T., \& Kassim, S. (2019). Exploring green banking performance of Islamic banks vs conventional banks in Bangladesh based on Maqasid Shariah framework. Journal of Islamic Marketing, 11(3), 729-744. https:// doi.org/10.1108/JIMA-10-2017-0105

Lee, H., Kim, J., \& Kim, J. (2007). Determinants of success for the application service provider: An empirical test in small businesses. International Journal of Human-Computer Studies, 65(9), 796-815. https://doi.org/10.1016/j.ijhcs.2007.04.004 
Magnier-Watanabe, R., \& Senoo, D. (2008). Organisational characteristics as prescriptive factors of knowledge management initiatives. Journal of Knowledge Management, 12(1), 21-36. https://doi. org/10.1108/13673270810852368

Masukujjaman, M., \& Aktar, S. (2014). Green banking in Bangladesh: A commitment towards the global initiatives. Journal of Business and Technology (Dhaka), 8(1-2), 17-40. https://doi.org/10.3329/jbt.v8i12.18284

Premkumar, G., \& Roberts, M. (1999). Adoption of new information technologies in small businesses. Omega The International Journal of Management Sciences, 27, 467484.

Ratanya, F. C. (2017). Institutional repository: Access and use by academic staff at Egerton University, Kenya. Library Management, 38(4/5), 276-284. https://doi.org/10.1108/ LM-02-2017-0018

Rifat, A., Iqbal, M., Nisha, N., \& Sharif, A. A. (2017). Acceptance of green banking framework in Bangladesh: The case of Islamic banks. Journal of Islamic Economics, Banking and Finance, 13(2), 152-178.

Sahoo, B., Singh, A., \& Jain, N. (2016). Green banking in India: Problems and prospects. International Journal of Research -Granthaalayah, 4(8), 92-99. https://doi. org/10.5281/zenodo.61169

Samina, Q. S., \& Hossain, M. N. (2019). Current position of banks in the practice of green banking in Bangladesh: An analysis on private sector commercial banks in Bangladesh. SSRN Electronic Journal. Retrieved from https://ssrn.com/ abstract $=3308682$

Selevičienė, E., \& Burkšaitienè, N. (2015). University students' attitudes towards the usage of web 2.0 tools for learning Esp. a preliminary investigation. Socialiniu Mokslu Studijos / Societal Studies, 7(2),
270-291. https://doi.org/10.13165/SMS-157-2-07

Shantha, A. A. (2019). Customer 's intention to use green banking products: Evidence from Sri Lanka. International Journal of Scientific and Research Publications, 9(6).

Shaumya, S., \& Arulrajah, A. (2017). The impact of green banking practices on bank $\square \mathrm{s}$ environmental performance: Evidence from Sri Lanka. Journal of Finance and Bank Management, 5(1), 77-90. https://doi. org/10.15640/jfbm.v5n1a7

Steinar, K. (1996). Interviews: An introduction to qualitative research interviewing. Thousand Oaks CA: Sage Publications.

Tara, K., Singh, S., Kumar, R., \& Sundararajan, M. (2019). Geographical locations of banks as an influencer for green banking adoption. Prabandhan: Indian Journal of Management, 12(1), 21-35. https://doi. org/10.17010/pijom/2019/v12i1/141425

The World Bank. (2017). UN environment and World Bank Group initiative: Roadmap for a Sustainable Financial System. United Nations Environment Programme and the World Bank Group.

The World Wide Fund for Nature. (2010). UAE has the world's largest environmental footprint. Retrieved December 6, 2018, from https://www.thenational.ae/uae/ environment/uae-has-world-s-largestenvironmental-footprint-1.525694

UAE Ministry of Climate Change and Environment (MOCCAE). (2017). UAE State of Green Economy report 2017. The United Arab Emirates. Retrieved from http://www.moccae.gov.ae/assets/ e3bd136a/uae-state-of-green-economyreport-2014.aspx

UAE Ministry of Environment and Water (MoEW). (2016). State of Green Finance in the UAE The first national survey on contributions of financial institutions to Green Economy. Dubai, United Arab 
Emirates. Retrieved from www.moew.gov. ae

Uddin, M. N., \& Ahmmed, M. (2018). Islamic banking and green banking for sustainable development: Evidence from Bangladesh. Jurnal Ilmu Ekonomi Syariah (Journal of Islamic Economics), 10(101), 97-114. https://doi.org/10.15408/aiq.v10i1.4563

Venkatesh, Morris, Davis, \& Davis. (2003). User acceptance of information technology: Toward a unified view. MIS Quarterly, 27(3), 425-478. https://doi.org/10.2307/30036540

Venkatesh, V., Thong, J. Y. L., \& Xu., X. (2012). Consumer acceptance and use of information technology: Extending the unified theory of acceptance and use of technology. MIS Quarter, 36(1), 157-178. Retrieved from https://www.jstor.org/ stable/41410412

World Bank Group. (2018). CO2 emissions (kt). Retrieved January 9, 2019, from https:// data.worldbank.org/indicator/EN.ATM. CO2E.KT?end $=2014 \&$ locations $=$ AE\&start $=1960 \&$ view $=$ chart

Worldatlas. (2019). Countries with the largest ecological footprints. Retrieved January
14, 2019, from https://www.worldatlas. com/articles/countries-with-the-largestecological-footprints.html

www.scopus.com. (2019). Analyse Search Results. Retrieved February 10, 2019, from https://www.scopus.com/ term/analyzer.uri? sid $=7 \mathrm{c} 3785 \mathrm{bc} 00 \mathrm{f}$ e 514b773b9160a6495df7\& origin= resultslist $\& \mathrm{src}=\mathrm{s} \& \mathrm{~s}=\mathrm{TITLE}-\mathrm{ABS}$ KEY\%28green+banking\%29\&sort=plf-f\& $\mathrm{sdt}=\mathrm{b} \&$ sot $=\mathrm{b} \& \mathrm{sl}=28 \&$ count $=240$ \&analyze Results $=$ Analyze + results $\&$ txGid $=89 \mathrm{c} 2 \mathrm{c} 04$ 374c99c5bf2efc0c3811d9105

Yin, W., Kirkulak-Uludag, B., \& Zhang, S. (2019). Is financial development in China green? Evidence from city-level data. Journal of Cleaner Production, 211, pp.247-256. https://doi.org/10.1016/j. jclepro.2018.11.106

Zhixia, C., Hossen, M. M., Muzafary, S. S., \& Begum, M. (2018). Green banking for environmental sustainability-present status and future agenda: Experience from Bangladesh. Asian Economic and Financial Review, 8(5), 571-585. https://doi. org/10.18488/journal.aefr. 2018.85.571.585 